\title{
Orpheus and Eurydice in the Middle Books of The Faerie Queene
}

The commendatory sonnet by 'W. S.' appended to the first edition of The Faerie Queene hails Spenser as the 'Brittayne Orpheus,' and modern critics have thought the author was onto something. Thomas Cain in 1971 made the case that Spenser 'use[s]...the Orpheusfigure to assert and assess his own role as poet' across his works; more recently Patrick Cheney has talked about Spenser's 'Orphic career'. ${ }^{1}$ In Spenser criticism at large, the idea that Spenser wants to present himself as another Orpheus is frequently mentioned, though rarely discussed in much detail. Given all this attention to the importance of Orpheus in Spenser's self-presentation, it is remarkable that an extremely curious feature of Spenser's treatment of the Orpheus-myth has received so little comment, and its implications for our understanding of Spenser's conception of his own role and powers remain unexplored. It concerns his treatment of Orpheus' greatest exploit, his katabasis in the attempt to recover his wife Eurydice from the Underworld. In the version best known today, the episode ends in tragic failure: though Orpheus with his enchanting song succeeds in charming the gods of the Underworld to consent to Eurydice's return, he breaks the condition imposed on him that he should not look back at her before they are both safely again in the upper world, and so loses her a second time, and irrevocably. Spenser refers to the myth several times across his works, but consistently presents Orpheus' attempt as successful, and Eurydice as restored to life. To list the most explicit examples, E.K.'s gloss to October 28 states in no uncertain terms that Orpheus 'by his excellent skil... recouered his wife Eurydice from hell'; in 'The Ruines of Time', the Muses are said simply to have sent Eurydice 'back againe to life' for Orpheus' sake (392); and in Book IV of The Faerie Queene Scudamour recalls how 'Orpheus did recoure / His Leman from the Stygian Princes boure'. (IV.x.58) The single exception to this rule, the only place where Spenser makes any reference to the supposed ultimate failure, is a telling one: it is in 'Virgils Gnat', Spenser's direct translation of the Culex, a poem from the Appendix Vergiliana which Spenser probably believed was (as his title presents it) an authentic work by Virgil.

The exception is telling because it is in Virgil that we find the earliest known reference to Orpheus' supposed ultimate failure to recover Eurydice. The epyllion which concludes the fourth Georgic tells the now familiar story, in which Eurydice dies, stung by a serpent, as she flees attempted rape by Aristaeus, and Orpheus' attempt to rescue her from Hades is thwarted by his rash backward glance. The author of the Culex reproduces the backward glance and final loss from the Georgics as part of a multi-faceted pastiche of all three of Virgil's canonical works, to produce an ostentatiously — even parodically_Virgilian poem. ${ }^{2}$ None of the earlier sources for this episode of the Orpheus myth make any reference to the supposed failure, all speaking as though he was successful in his attempt. Spenser could have known at least three of these Greek sources: even though I see no reason to doubt that his Greek was proficient, after his education at the Merchant Taylor's school and at Cambridge, he would also have had access to Latin translations of Euripides' Alkestis, Plato's Symposium, and the Lament for Bion. ${ }^{3}$ The second of these is a special case. In what seems a flamboyantly original twist on a traditional tale, Plato does not exactly have Orpheus succeed, but the terms of the failure are quite different to what we find in Virgil: Orpheus is not a true lover, according to the speaker Phaedrus, because he did not have the courage to 
sacrifice his life in exchange for his beloved's as Alkestis did, and in punishment he is deceived by the gods, who give him not Eurydice but a mere simulacrum of her. There is no suggestion that this phantom is then lost, and indeed the punishment only works if we assume that, whatever he took back with him to the upper world, he took it back successfully, and continued to live with it, in a delusion of happiness befitting his sham love. In all the other Greek texts there is no shadow over Orpheus' success. The third example is especially interesting, since Spenser imitates the Lament for Bion (a pastoral elegy, commonly attributed to Moschus, for his predecessor and poetic teacher Bion) in the Nouember eclogue of The Shepheardes Calender and in 'Astrophel', Spenser's own pastoral elegy for Sidney. ${ }^{4}$ The poem ends with the hope that Persephone will be charmed by the song of Bion, the 'Doric Orpheus', into releasing him from the underworld as once she released Eurydice.

It seems clear, and most classicists agree, that there was at least an alternative tradition before Virgil which held that Orpheus successfully reclaimed his wife. Whether the tragic ending of Virgil's version was his own innovation (as the introduction of Aristaeus to the story is generally judged to be) is more widely debated. C. M. Bowra suggests that there may have been some Hellenistic source for the tragic version, now lost but known both to Virgil and Ovid (who also includes the backward glance and second loss in his version in the Metamorphoses). ${ }^{5}$ Even if that were the case, however, Virgil in the Georgics would still at the very least be selecting an obscure variant of the myth over the better known tradition. ${ }^{6}$ It remains a possibility that he invented it, but we can at any rate say that his poem was responsible for popularizing it. ${ }^{7}$ After Virgil it became canonical (Ovid's imitation in the Metamorphoses is especially influential for the period we are dealing with; Boethius also follows Virgil's version in the Consolation of Philosophy (Book 3, metrum 12), adding an explicit moral allegory which was enormously influential in the Middle Ages), and later references to the successful Orpheus are rare. ${ }^{8}$ The familiarity of the Virgilian version is such that, in our own time, most scholars outside the discipline of Classics seem unaware that the story ever had, in classical times, a happy ending. When they are aware of it, they mention it only as a recondite curiosity, perhaps worthy of mention in a gloss, but quite overridden for interpretive purposes by the Virgilian version, which is taken as normative. Thus, when Spenser in Epithalamion compares his song to Orpheus', critics find that it imports a sinister note of foreboding quite at odds with the joyously triumphal mood of the poem, and when Scudamour compares his winning of Amoret to Orpheus' recovery of Eurydice, they reflect that it ironically anticipates the loss he is about to endure when Amoret is abducted by Busirane. ${ }^{9}$ The reader, they assume, is intended to supply the tragic Virgilian ending and to register Spenser's failure to mention it as an ironic omission or suppression. But Spenser's remarkable consistency in entirely ignoring that ending - everywhere, except in the single poem spoken in Virgil's voice - surely suggests instead that the reader is intended to recognize that Spenser is offering up a different version of the myth altogether. The fact, in particular, of that single exception, would seem to confirm that he conceives this alternative version as the original form of the myth before Virgil had turned it into a tale of tragic failure. Whatever we may decide about whether Eurydice's second loss was Virgil's innovation, Spenser seems to have thought it was, and to have regarded it as a late falsification of the original, 'true' form of the myth. 


\section{Orpheus in 'The Book of Virgil'}

Virgil's Orpheus epyllion at the end of the Georgics occupies a pivotal position in the evolution of his career, and in the progress of that tripartite body of work-the Eclogues, Georgics and Aeneid - which so foregrounds its own overarching shape that it invites consideration as a single 'Book of Virgil' ${ }^{10}$ It is fraught with significance reflecting its position in that overarching and value-laden shape. Coming near the end of the middle work, the Georgics, it recalls key features of the Eclogues. In his passionate grief, Orpheus resembles the frenzied lovers of the pastoral poems - the Corydon of eclogue 2, the suicidal goatherd of Damon's song in eclogue 8, and particularly the Gallus of eclogue 10. Compare Orpheus lamenting after Eurydice's second loss with the prone figure of the lovesick Gallus in the eclogue:

Septem illum totos perhibent ex ordine menses rupe sub aeria deserti ad Strymonis undam fleuisse, et gelidis haec euoluisse sub antris mulcentem tigres et agentem carmine quercus... (Georgics 4.507-510)

[For seven whole months on end, they say, under a towering cliff near the wave of lonely Strymon, he wept, and unfolded this tale within icy caves, charming the tigers and moving the oaks with his song...]

Illum etiam lauri, etiam fleuere myricae. pinifer illum etiam sola sub rupe iacentem Maenalus, et gelidi fleuerunt saxa Lycaei. (Eclogues 10.13-15)

[Even the laurels, even the myrtles wept for him. Even pine-covered Maenalus, and the stones of icy Lycaeus, wept for him as he lay alone beneath the cliff.]

The episode reemphasizes the Eclogues' anti-erotic treatment of love as a form of madness (furor and dementia are the words used at Georgics 4.495 and 488, echoing Eclogues 2.69 and 10.60), leading only to despair and death.

The Orpheus of the Georgics also recalls the Eclogues' frequent but conflicted references to the quasi-magical power of song. ${ }^{11}$ The description of Orpheus silvasque sequentis ('with the woods following him'), carved on Damoetas' cup in eclogue 3 (1.46), is the first mention of Orpheus in Latin poetry. In eclogue 6, where the wood-god Silenus sings a mythological epyllion more delightful than Orpheus' songs (Eclogues 6.30), we see the Muses giving Virgil's fellow poet Gallus pipes with the Orphic power to draw trees down the hillside (11. 69-71) - a divine power which will be defeated by the madness of love in eclogue 10, where Gallus succumbs to grief and abandons poetry. Moeris is hailed in eclogue 8 as a master of songs and spells (carmina), able even to rouse spirits from the grave (8.95-99), but in eclogue 9 he is reduced to impotent curses when driven from his farm by Octavian's soldiers, reflecting bitterly carmina tantum / nostra valent, Lycida, tela inter Martia, quantum / Chaonias dicunt Aquila veniente columbas ('Our songs have as much power amid the weapons of war, Lycidas, as they say Chaonian doves do when the eagle comes', 9.12-13). 
Meanwhile, in eclogues 1 and 5, the power of the poet to animate the landscape is evoked only to be put at the service of the same regime by Tityrus and Menalcas. The Eclogues are famously ambivalent about the poet's relation to political power; suggestions of Orphic power seem to offer a degree of independence, but it is uncertain and limited, and more safely exercised in the service of the regime than in opposition.

The Georgics episode seems to close down the possibility of independent power. The figure of Orpheus, the poet with quasi-divine magical powers, is balanced with that of Aristaeus, the farmer and apiculturist, in the frame narrative. In a series of parallels and pointed contrasts between their stories, the values of obedience to authority embodied both in Aristaeus and his bees emerge triumphant, while Orpheus' attempt to transcend and defy the limitations of human life ends in tragic failure. We meet Aristaeus lamenting the death of his bees in prayer to his divine mother, the nymph Cyrene. She brings him down to her underwater cave, and after making pious offerings to Ocean and Nereus advises him to consult the prophetic Proteus. Proteus explains that the cause of the bees' death is Orpheus' anger, since his bride Eurydice died of a snake-bite when fleeing Aristaeus, who wanted to rape her; he goes on to recount the katabasis, its failure, and Orpheus' subsequent grief and death. Cyrene then instructs her son on how to propitiate the spirits of Orpheus and Eurydice, and the nymphs also angered by her death, through ritual sacrifices. Aristaeus follows the instructions punctiliously, and from the rotten flesh of one of the victims a new swarm of bees is born, in the first bugonia (so that the entire episode is an aetiology for the apicultural practice Virgil is teaching his putative addressees, the Italian farmers). Aristaeus is the guilty party, the cause of Eurydice's death and Orpheus' grief, because of his brutally selfish attempted rape; when Orpheus' lamentations are compared later to those of a nightingale whose brood has been killed by a durus arator ('hard ploughman', Georgics 4.512), Aristaeus is also reflected in this incarnation of the Virgilian farmer, pressing on pragmatically and unfeelingly in his labor with no pity for those he destroys. But fate is nevertheless on his side. Both Aristaeus and Orpheus lament deaths (Aristaeus his bees', Orpheus Eurydice's); both make a katabasis (Aristaeus into Cyrene's cave, Orpheus into Hades), but the labor, pragmatism, and above all pietas of the farmer are rewarded with the renewal of his bees, where the love and art of Orpheus end in defeat. Orpheus' transcendent powers partake of two kinds of enthousiasmos or divine madness described in Plato's Phaedrus: the rapture of passionate love, and the rapture of poetic inspiration which Plato contrasts with the mere techne of the uninspired poet (245). Though with poignant regret, Virgil's ending presents both erotic and poetic furor as self-defeating and futile, giving no power against the 'ruthless tyrant' (4.492) Dis, whom Orpheus seeks to oppose. The obedient pietas which characterizes Aristaeus has been paramount in the teachings Virgil has offered his putative addressees, the farmers of Rome (in primis venerare deos! 'Above all, honour the gods,' Georgics I.338) and the work celebrates as its chief value the farmer's toil in the service of the community. The bees which are Aristaeus' care have been described earlier in Book 4, in semi-humorously anthropomorphic terms, as a kind of ideal society of sexless and selfless citizens, wholly dedicated to their ruler and the good of the commonwealth. They reflect, and perhaps to a degree parody, traditionally Roman values, and are even referred to as little Romans, parvos Quirites (4.201). Their lack of individuality and utter immunity to sexual desire, let alone romantic love, make them the very opposite of Orpheus, whose 
passionate attachment to a particular individual, even when parted by death, leads in Virgil's account to his refusal to contemplate marriage to another, and to a solipsistic and complete withdrawal from society to indulge in lonely lament. Aristaeus, meanwhile, resembles them perhaps as nearly as a human could: he may experience sexual desire as a physical impulse, but acts on it pragmatically and unfeelingly in his attempted rape, and is so far from loving Eurydice that he has to be reminded who she was and informed of her death by Proteus. Virgil's epyllion certainly expresses and provokes pity for Orpheus, and the reader may well feel that the brute pragmatism of the farmer and the continuance of the bees' impersonal society are not worth the sacrifice of the values of art and love embodied in Orpheus, ${ }^{12}$ but nevertheless it is to them that the future belongs, according to the fourth Georgic.

Having thus consigned Eurydice and finally Orpheus to death, and celebrated Aristaeus' victory, the poem closes with a sphragis, contrasting Augustus' glorious military campaigns with Virgil's own 'backward glance' at the composition of the Eclogues. These closing lines are wistful and idyllic in tone, but nevertheless denigrate pastoral composition as youthful play, the product of ignoble idleness, and relegate it firmly to Virgil's pastimplicitly in favour of the poetic 'temple' to Augustus which he has promised (at the beginning of the third Georgic) to build. This temple will take form as the Aeneid. The Georgics (like the future epic) are not the product of poetic rapture, but composed to order, at the 'command' of Maecenas (tua, Maecenas, haud mollia iussa, 3.42). Indeed, according to Servius' gloss on Eclogues 10.1 (substantially repeated in his gloss to Georgics 4.1), the Orpheus episode or some portion of it was itself written at Augustus' order (iubente Augusto) to replace a passage praising Virgil's friend and fellow poet Gallus, after his disgrace and forced suicide. Several critics have suggested that Virgil obliquely mourns his Gallus through the tragic figure of Orpheus. ${ }^{13}$ Most are sceptical about Servius' claim that what we have was written to order, to replace a lost passage of laudes Galli, but in a forceful defence of Servius, Jacobson argues 'that the original Georgics 4 contained a successful recovery of Eurydice' as well as praise of Gallus, and that Virgil devised the tragic ending to Orpheus' katabasis precisely to provide 'a kind of mythological paradigm for Gallus' sad fate', 'so as to be able to concretely find expression for his deep grief' at the death of his friend. ${ }^{14}$ Under such readings, Virgil's reference to Dis as an immitus tyrannus ('merciless tyrant') at 4.492 suggests harsh criticism of Augustus' treatment of Gallus. But Virgil does this indirectly, through his newly created 'mythological paradigm', as he must do to avoid incurring the anger of the vengeful 'god' himself. With the close of the Georgics, Virgil relegates his own Orphic side to the past and embraces the dutiful public service and techne embodied in Aristaeus and his bees.

In the Aeneid, the Augustan values of labor and pietas embodied by Aristaeus continue to be celebrated, as Aeneas learns to avoid the self-destructive and solipsistic amatory passion of the Orpheus of the Georgics and to devote himself rather to the good of his community. The episode which sets the tone is another reworking of Orpheus' katabasis, as Aeneas in Book 2 reenters burning Troy in an attempt to recover his wife, Creusa, but instead meets and heeds the advice of her ghost, who bids him banish grief for her, accept the will of the gods, and follow the destiny which will lead to Rome and to Augustus' reign. ${ }^{15}$ Quid tantum insano iuvat indulgere dolori? ('What does it avail to indulge like this in insane grief?' Aeneid 2.776), she asks, recalling Eurydice's reproach to Orpheus in the Georgics, 
quis et me miseram et te perdidit, Orpheu, quis tantus furor? ('What madness so great, Orpheus, has destroyed both miserable me and yourself?' Georgics 4 494-5) and Apollo's question to the lovesick Gallus in eclogue 10, Galle, quid insanis? ('Gallus, what madness is this?' Eclogues 10.22) The fact that Aeneas' wife was called 'Eurydice' in one of Virgil's sources, the Cypria, makes the parallel all the more striking. Aeneas learns to be an Aristaeus rather than an Orpheus, and political imperatives will continue to outweigh amatory ties in the rest of his history, as they also govern and shape Virgil's poem (at least on its surface).

The Orpheus episode in the Georgics thus participates in grand movements across Virgil's work: the turn from Amor towards Roma, from pastoral towards epic, from the political ambivalence of the Eclogues to the laureate's service to the regime, from the poetics of inspired furor to the poetics of patronage. Spenser recognized what Virgil was doing with his tragic ending in all these respects, and engages antagonistically with the purposes and values enshrined in the shape of the Book of Virgil through his recalibration of the Orpheus myth, and through repeated reworkings of Virgil's epyllion. ${ }^{16}$ Indeed, one can even say that each time Spenser wishes to draw attention to his divergence from the career-path of Virgil and all that it implies, he marks that divergence by returning to the tale of Orpheus and Eurydice. ${ }^{17}$ Piers' comparison of Cuddie to Orpheus, and E.K.'s provocative gloss on Orpheus' success, occur in the context of October's recusatio of higher genres, framed precisely as a rejection of the Virgilian career. After nevertheless ascending from pastoral to epic, Spenser swerves aside from that career-path again when he interrupts his epic, and The Ruines of Time and Epithalamion, with their Orpheus allusions, appear before he resumes it. As we shall see, the books of The Faerie Queene which book-end that long break between the two editions of the epic rework Virgil's Orpheus epyllion on a large scale. Turning at the end of his career to a non-Virgilian and quintessentially Orphic genre in the Fowre Hymnes (since Orpheus was still believed to be the author of the so-called 'Orphic Hymns'), Spenser cites Orpheus' katabasis as an example of the courage of lovers (defying Phaedrus'

judgement in the Symposium). Spenser's pointed revision of Virgil's fourth Georgic is intended to combat the ideology shaping that poem and Virgil's whole cursus - an ideology which subordinates Amor to Roma, individual to state, poetic furor to the patronage relationship, and the poet himself to the princeps. I have written elsewhere of the role played by Orpheus in Spenser's pastorals. ${ }^{18}$ Here I shall consider the sustained engagement with the Orpheus myth to be found at the heart of his epic.

\section{Rape and Sympathy in the Tale of Amoret and Scudamour}

Orpheus' rescue of Eurydice underlies two of the major plots intertwined in the middle books of The Faerie Queene - that of Amoret and Scudamour and that of Florimell and Marinell. It is in the context of the former that Spenser makes his explicit allusion to the myth. The beginning of the story of the love of Amoret and Scudamour is told in Book IV, canto $\mathrm{x}$, where Scudamour relates how he first dragged her, struggling and pleading (if not actually kicking and screaming), from the Temple of Venus. He ends by comparing his success to Orpheus' recovery of Eurydice.

No lesse did Daunger threaten me with dread, 
When as he saw me, maugre all his powre,

That glorious spoyle of beautie with me lead,

Then Cerberus, when Orpheus did recoure

His Leman from the Stygian Princes boure. (IV.x.58)

As in the Shepheardes Calender and in The Ruines of Time, and as in the Greek sources, there is no hint of Virgil's tragedy here. Spenser's scholarly editor Hamilton knows that there existed an alternative tradition in which Orpheus actually accomplished the feat, and mentions it in his gloss, but nevertheless soon reverts to the Virgilian version:

S. may refer to the less common version of the myth in which Orpheus recovered Eurydice, as he seems to do in SC Oct. 28-30, though the subsequent history of Scudamour's courtship parallels the more common version: Orpheus lost Eurydice, as Scudamour loses Amoret, because he was overcome by desire....The myth relates also to Amoret who was seized and wounded on her wedding-night as Eurydice was mortally wounded in her heel on her wedding-night, by which 'is meant lustfull love' (E.K. on March 97). (Hamilton, ad IV.x.58.4-5)

Hamilton's gloss says several different things at the same time, to rather confusing effect. First, Scudamour's abduction of Amoret parallels Orpheus' attempted rescue of Eurydice, as Scudamour himself says: on the one hand, this 'may refer to the less common version' of the myth, in which Orpheus' attempt is successful, but on the other (and Hamilton clearly prefers this idea) an alleged irony predicts Scudamour's imminent loss of Amoret, in her abduction by Busirane, as a parallel to Orpheus' ultimate failure in Virgil. As a consequence of this supposed parallel, Hamilton draws the implication that Scudamour loses Amoret (to Busirane) 'because he was overcome by desire' - since Orpheus' backward glance in Virgil is motivated by the 'madness' (dementia, 4.488) of love. ${ }^{19}$ (This does not, incidentally, resonate very clearly with the account of the abduction as we hear it in IV.i, where Amoret falls prey to Busirane while Scudamour and 'euery man/Surcharg'd with wine, were heedless and ill hedded,/All bent to mirth' (IV.i.3) - Scudamour seems culpable here for outright neglect of Amoret, 'ill of friends bestedded,' rather than for desiring her too fiercely.) Then Hamilton draws another parallel (at odds with the first two), between Amoret's abduction by Busirane and Eurydice's (first) death, when she is bitten on the heel by a serpent, because both disasters befall the women on their wedding day, which is an important observation (though the addition of E.K.'s gloss from March is misleading: E.K. is talking about Achilles, not Eurydice, here, and neither here not anywhere does Spenser mention the serpent stinging Eurydice, let alone draw this moral from it). Within Hamilton's gloss at x.58, then, we are asked to consider Busirane's abduction as corresponding at once to the beginning of the story of Orpheus and Eurydice and to its end. ${ }^{20}$

This is not unimaginable, of course, but it is a little clumsy. In fact there is no need for such complexity, and the reader is already equipped, by this stage in the poem, to see that Amoret's story maps onto Eurydice's in a quite different way - one which is simpler and more elegant. There is irony at work in Scudamour's allusion, but it is not the irony seen by Hamilton. Rather, while helpfully alerting us to the connection between his own story and the 
myth, Scudamour nevertheless fails to recognize which part of the myth his own actions parallel. His abduction of a reluctant Amoret by force from the Temple of Venus, the beginning of the story of their 'love', corresponds to the beginning of Eurydice's as it appears in Virgil-Aristaeus' attempted rape. ${ }^{21}$ In Spenser as in Virgil, this leads on to her loss, when Amoret is abducted on her wedding-day, as Eurydice dies on hers. The House of Busiraneits portal guarded, as we are told at III.xi.21, by sulphurous flames strongly evocative of Hellmouth - thus emerges retrospectively as a version of the Underworld, where Eurydice is imprisoned until her release by Orpheus, and (in Virgil's tragic version) after the failure of his attempt. (Compare the seven months of Amoret's imprisonment (III.xi.10) with the seven months of Orpheus' grieving which Virgil specifies after Eurydice's second loss (Georgics 4.507).) The reader has known since the end of Book III what happened next: with the boldness which characterizes Britomart throughout, as she pursues her quest 'with loue to frend', Spenser's female knight of Chastity or married love braves the flames and enters the castle, daring to 'inuade' 'a god'. There she discovers Amoret, who

\section{like a dreary Spright,}

Cald by strong charmes out of eternall night,

Had Deathes owne ymage figurd in her face... (III.xii.19)

- like the shade of Eurydice retrieved by Orpheus' songs, in other words. ${ }^{22}$ Britomart forces Busirane to 'Restore' Amoret 'vnto her health, and former state' (35), and successfully brings her away. Britomart's rescue of Amoret from Busirane's house clearly corresponds to Orpheus' successful recovery of Eurydice from Hades. This is the end of the story of Amoret and Scudamour in the 1590 edition. With the changed ending to Book III in the 1596 edition it is still the last real event in that story: thereafter, their relationship is left in limbo, as both continue to search for eachother in vain, even when Amoret is present at Scudamour's account of his initial abduction, yet goes mysteriously unnoticed by him. His allusion to Orpheus' rescue of Eurydice at the end of that account misrepresents his own actions there, but nevertheless unveils (for the reader looking back) the mythical intertext of the rescue of Amoret in III.xii.

In all of this, there is no allusion to or imitation of the tragic ending of Virgil's tale. Even when the changed ending of III.xii for the 1596 edition excises the reunion of the lovers, there is no suggestion that Amoret's rescue is undone; and we should note that the reunion is prevented here by Scudamour's premature despair - a faint-heartedness which seems the very opposite of the excess of desire which causes Virgil's Orpheus to lose his Eurydice in the end. ${ }^{23}$ What marks out the distance between III.xii (the narratological beginning and chronological end of the story) and IV.x (its narratological end and chronological beginning) is the gap between Spenser's imitation of the myth in its original Greek form and Scudamour's misplaced allusion to it; between Britomart's real accomplishment of the Orphic feat and Scudamour's hubristic boast that he has accomplished it where he has not; and between Orpheus' successful recovery of Eurydice at the end of the myth in its original form, and Aristaeus' rapacious pursuit at the beginning of Virgil's version. 
Many critics have noted that Scudamour's actions in the Temple of Venus accord ill with Spenser's explicit teachings about the importance of mutuality and the evil of exercising 'maistrye' in love. ${ }^{24}$ As Britomart explains in canto i of Book III, love may not

be compeld by maisterie;

For soone as maisterie comes, sweet loue anone

Taketh his nimble wings, and soone away is gone. ${ }^{25}$ (III.i.25)

Indeed, immediately before Scudamour proudly relates the story of the abduction, the authoritative figure Arthur has reminded the assembled audience, including Scudamour, that to ladies 'the world this franchise euer yielded, / That of their loues choise they might freedom clame.' (IV.ix.37) In such a context, Scudamour's boasts of his wilfully pitiless deafness to the pleading of Amoret as he drags her, unwilling, from the Temple can only jar:

With that my shield I forth to her did show,

Which all that while I closely had conceld;

On which when Cupid with his killing bow

And cruell shaftes emblazond she beheld,

At that sight therof she was with terror quald,

And said no more: but I which all that while

The pledge of faith, her hand engaged held,

Like warie Hynd within the weedie soyle,

For no intreatie would forgoe so glorious spoyle....

She often prayd, and often me besought,

Sometime with tender teares to let her goe,

Sometime with witching smyles: but yet for nought,

That euer she to me could say or doe,

Could she her wished freedome fro me wooe... (IV.x.55-57)

His reliance on superior physical force, his reference to her as his 'spoyle' (not only here but also in stanzas 3 and 58), his willed deafness to her pleas, and his terror tactics are all starkly opposed to Arthur's lesson on courtship. In fact, the torment to which Busirane subjects Amoret is merely a continuation of her treatment at the hands of Scudamour: her problem throughout is that she is reified by rapacious males who seek to overmaster her will. The image which Scudamour uses so deliberately to terrorize Amoret and her companions is that same 'cruell Cupid' (III.xi.38), armed with 'mortall bow and arrows keene' (III.xi.48), whose statue presides over the first hall of Busirane's house, and who follows the bleeding Amoret in the midnight masque, 'reioyc[ing] in his cruell mind' as he beholds 'his proud spoyle of that same dolorous / Faire Dame' (III.xii.22). It is also the same Cupid to whom the unreformed lover at the beginning of the Amoretti prays to humble his mistress so that he may laugh at her (Amoretti 10). ${ }^{26}$ Spenser's sonnet sequence, presented as an account of his own courtship and betrothal, charts the gradual education of the lover-poet, to the point where he no longer desires conquest, but recognizes mutuality as the ideal of married love: 
Sweet be the bands, the which true loue doth tye, without constraint or dread of any ill:

the gentle birde feeles no captiuity within her cage, but singes and feeds her fill.

There pride dare not approach, nor discord spill

the league twixt them, that loyal loue hath bound:

but simple truth and mutuall good will,

seekes with sweet peace to salue each others wound. (Amoretti 65)

At this point in the sonnet sequence, the lady need no longer fear to lose her liberty, and can therefore freely accept his suit. Scudamour has conspicuously failed to develop such an understanding.

By contrast, Britomart, embodying Spenser's conception of true Chastity as faithful married love, and playing the role of Orpheus in her recovery of Amoret, is driven by 'good will', a purely selfless 'pitty' both for Scudamour's grief (III.xi.8) and for 'gentle Ladies helpless misery' (xi.18) which prompts her to rescue Amoret and 'salue' her 'wound' (in the words of Amoretti 65), or die in the attempt. 'Empassiond sore' in her sympathy for both the grieving Scudamour and the suffering Amoret, she acts on her pity in a way quite opposite to Scudamour, who takes such pride in his own stoical indifference to Amoret's tears in IV.x. It is unsurprising that Scudamour finds her offer of help hard to assimilate:

What huge heroicke magnanimity

Dwels in thy bounteous brest? what couldst thou more,

If she were thine, and thou as now am I? (III.xi.19)

His own limited moral purview can comprehend such courage only in the context of a selfish desire to possess 'spoyle'. Amoret, quite used by now to being taken by force, seems herself to expect similar treatment at Britomart's hands after her rescue, and her first words are to offer herself as Britomart's 'vassall' (xii.39): her promise to spread Britomart's fame abroad, reminding her that such glory is the proper reward for 'vertue', is a rhetorical attempt to ward off the sexual subjection she evidently expects. Her fears are of course groundless, and this is not only because her saviour is a woman, but also because she is a sympathetic soul: for Britomart it is 'reward enough' to have seen Amoret 'in safety' (xii.40).

The recurring image of the hunted deer brings all of this into peculiarly sharp focus. We have seen in the passage quoted above how Scudamour compares Amoret to a 'warie Hynd within the weedie soyle'. (IV.x.55) The image presents Scudamour in the role of the huntsman or predator, to whom the deer is his 'glorious spoyle', which he will by no means relinquish. ${ }^{27}$ In the original ending of Book III, cancelled in the 1596 edition, the reunion of the lovers is expressed through the same imagery, but with quite different application. On seeing Amoret emerge, Scudamour starts up from the ground where he has been lying in literal dejection,

And to her ran with hasty egernesse, 
Like as a Deare, that greedily embayes

In the coole soile, after long thirstinesse,

Which he in chace endured hath, now nigh breathless. (1590, III.xii.44)

Here, Scudamour has become the deer, while Amoret is the life-restoring water which refreshes him; there is no predator or huntsman in sight, and the 'chace' has been eluded or abandoned. The familiarity of the conventional trope of the hunt of love is such that we register a slight surprise to find the male lover, rather than the female beloved, compared to the hunted deer. ${ }^{28}$ The removal of any notion of predation is pointed, and the application to Scudamour of the conventionally female role prepares for the merging of their identities in the startling image of the hermaphrodite used in stanza 46 to describe their embrace, conveying the perfect reciprocity of their love. A third use of the image of the hunted deer occurs at the climax of the Amoretti:

Lyke as a huntsman after weary chace, Seeing the game from him escapt away, sits downe to rest him in some shady place, with panting hounds beguiled of their pray:

So after long pursuit and vaine assay, when I all weary had the chace forsook, the gentle deare returnd the self-same way, thinking to quench her thirst at the next brooke.

There she beholding me with mylder looke, sought not to fly, but fearelesse still did bide: till I in hand her yet halfe trembling tooke, and with her own goodwill her firmly tyde.

Strange thing me seemd to see a beast so wyld, so goodly wonne with her owne will beguyld. (Amoretti 67)

The lady here assumes the traditional role of the hunted deer, and the male lover that of the huntsman, yet the 'strange' scene is not the violent rapine and conquest of 'spoyle' expected at the end of a successful hunt, such as Scudamour feels he has achieved at the Temple of Venus. The lady comes freely to the lover, and rather than becoming 'pray' to the hounds, instead consents to be bound by (or to) him. The ambiguous syntax of line 12 allows alternative readings: either 'I bound her, and she consented to let me do so,' or 'I bound her with the bonds of her own intention', so that even within the imagined, metaphorical scene, the bonds tremble on the brink of evaporating from the physical into the purely metaphorical 'Sweet...bands, the which true loue doth tye', the bands of marriage described two sonnets earlier. This 'league', into which both partners enter voluntarily, is presented not as the unequal subjection of one to the other: rather, the lovers are presented as equal partners in a contract, where both freely give their word and agree to hold themselves and eachother to it. The binding in sonnet 65 is reciprocal: Elizabeth, in consenting to be bound, will 'make him bond that bondage earst dyd fly', and its image of the contentedly caged bird to describe the female beloved will return in sonnet 73 to describe the male lover, as he begs Elizabeth to 
'Gently encage' his heart in her bosom. These reciprocities are reminiscent of the way in which Scudamour, in the 1590 ending of Book III, takes up the position of the deer traditionally ascribed to the female beloved. Of course, the fundamental point in the sonnets is that, by this stage in the relationship and sequence, each is a lover and each is the beloved. Spenser's persona has 'the chace forsook', not so much in the sense that he has given up in despair, but rather in the sense that he has learned to view his beloved not as an object of 'spoyle' to be run down and overcome, but as a desiring subject like himself, whose goodwill and love he must earn by demonstrating his own respect and goodwill. It is through his ability and willingness to see himself and the relationship from her point of view, his striving to understand and meet her desires, that he has accomplished this, and it is because she can see that his lesson has been learned (and his predatory 'chace' forsaken) that the lady comes to him freely now.

In the 1590 edition of The Faerie Queene we never see Amoret and Scudamour together except in that closing embrace, and though the mutuality of their love is implied at the end of canto vi, where we learn (in an account of the beginning of their relationship which is hard to reconcile with Scudamour's in IV.x ${ }^{29}$ that Amoret chose Scudamour freely from many suitors at 'Faery court' (III.vi.52), we have no real opportunity to scrutinize Scudamour's attitude to or treatment of her. The ideal reciprocity suggested by the imagery of the 1590 ending to III.xii, evoking so strongly the mutual love which has evolved by the time of the betrothal in the Amoretti, is brought about entirely by proxy in the House of Busirane episode, with Britomart, acting here as an almost purely allegorical figure, embodying and performing the sympathy and care which need to be exercised by Scudamour as a partner in the relationship - the sympathy and care by which the Amoretti's lover-poet wins his lady's hand. In 1596, Spenser changes the outcome so as to be able to subject Scudamour's character and intentions to scrutiny, and the narrative he develops transforms Scudamour into a male lover who has precisely failed to learn the lesson described in the sonnet sequence. Where Spenser's persona learns over the course of the Amoretti to abandon his aggressive and reifying attitude to his beloved in favour of a respectful and mutual love, Scudamour in the 1596 edition does not, and when we see him last, in IV.x, he still regards Amoret as his 'spoyle', with all the predatory aggression implicit in the early sonnets of Spenser's sequence. ${ }^{30}$ The final irony in Scudamour's misapprehension is that he not only misjudges his own Aristaeus-like rape of Amoret as akin to Orpheus' rescue of Eurydice, but also misjudges Britomart's rescue of Amoret as rape, yielding to Ate's slanderous suggestions in Book IV and concluding that Britomart can only have been motivated (like himself) by selfish and rapacious desires. The 'heroicke magnanimity' of selfless and sympathetic love is truly beyond his ken.

Orpheus lends himself very naturally to representation as a shining example of faithful married love (and thus is often paired in the Greek references with Alkestis, who sacrificed her life in exchange for her husband's). Spenser's focus on sympathy as an essential part of this love is also interestingly connected to the Orpheus myth. For Orpheus accomplishes the rescue of Eurydice through his exceptional power as a singer to elicit pathos, moving the gods of the underworld to unwonted pity of their human victims. The power of music to rouse emotions is central to the topic of Orphic powers in E.K.'s glosses in October. ${ }^{31}$ Britomart of course does not use music or song in her rescue of Amoret, and 
exciting Busirane's pity is no part of her goal. But her own sympathetic responsiveness nevertheless evokes and emphasizes the importance of this arousal of sympathy as a moral motivation, and her responses are mirrored in Spenser's authorial interjections at the spectacle of the tortured Amoret ('O ruefull sight', III.xii.20; 'Ah who can loue the worker of her smart?' III.xii.31), which at once express his pity and ostentatiously elicit the reader's, drawing attention to his own powers of poetic pathos. Britomart is not a poet, but nevertheless her moral nature is intimately related to Spenser's conception of his own poetic powers and purpose. David Lee Miller remarks suggestively, in 'The Chastity of Allegory,' that 'Book III aligns Britomart's quest with an implicit quest by the poet for a new register of erotic language. ${ }^{32}$ The House of Busirane is most often analysed in terms of Spenser's critique of Petrarchism, but the Petrarchan discourse with which Busirane cruelly 'pens' Amoret is descended in manifold ways from Roman amatory elegy. Busirane's masque of love is inspired by Petrarch's Triumph of Love in the Trionfi, in turn inspired by Cupid's triumphal procession as imagined by Ovid in Amores I.2. It is precisely the posturing of the elegiac lover which Virgil pastiches in his depiction of Gallus, dying of love in Eclogue 10, and in the Orpheus of the fourth Georgic who resembles him so closely, and Virgil shares the elegists' sense of love as a destructive madness, a torment, and a form of subjection. 'What madness so great has destroyed yourself and miserable me?' asks Eurydice in the Georgics. 'Love conquers all; let us too yield to love,' Gallus says resignedly in the tenth eclogue. Drawing out the implications of the rhetoric in his characteristic way, Ovid consents to be shackled by Cupid in the Amores, and in the Ars amatoria recommends that the women who cause such suffering be made to suffer. ${ }^{33}$ By forcing Busirane to reverse his charms - his poetic carmina-Britomart destroys the imprisoning edifice of this tradition of erotic discourse which stretches from Virgil and his contemporaries to the Petrarchists of the sixteenth century, a tradition founded on the identification of sexual love with suffering and subjection. Meanwhile she embodies the new language of love with which Spenser seeks to replace it. But when Miller describes Spenser's intention as 'a re-virginization of the culture's erotic imagination', (12) he momentarily mistakes the kind of 'chastity' to which Spenser's allegory aspires. He is responding here to the closing up of Amoret's wound in stanza 38 of canto xii, which strikes him as 'an almost pornographically explicit image of defloration-inreverse'. (12) But such an identification of sexual love and sadistic violence is precisely the malaise of the 'culture's erotic imagination' which Spenser figures forth in Busirane's house. ${ }^{34}$ The Busirane who collects rape-tapestries to deck his walls may associate vivisection with sexual penetration, but Spenser and Britomart know the difference between saving Amoret's life and restoring her virginity (which forms no part of their plan). The 'new register of erotic language' they are constructing is rather one which identifies sexual love with sympathetic understanding and care for the other, with salving wounds rather than inflicting them, and with the mutuall fulfilment of desire - an eros not opposed to caritas but one with it. This love has everything to do with the 'intimacy' Miller emphasizes at the end of his paper, but little to do with the virginity fetishized by Petrarchists, and embodied in the icy Belphoebe who envies her 'soueraigne salue' to Timias in canto v, or in the virginal Arethusa who is the muse of Virgil's tenth eclogue. ${ }^{35}$

The only pity of which Scudamour is capable, meanwhile, is self-pity, and in this too he resembles Virgil's Aristaeus. I have compared the seven months of Amoret's 
imprisonment by Busirane to the seven months which Orpheus spends grieving for the irrevocably lost Eurydice in Virgil's account, but when Britomart discovers Scudamour outside Busirane's house in III.xi, his lament strikingly recalls Aristaeus bemoaning the loss of his bees at the beginning of Virgil's epyllion. Scudamour accuses the heavens:

hast thou, Lord, of good mens cause no heed?

Or doth thy iustice sleepe, and silent ly?

What booteth then the good and righteous deed,

If goodnesse find no grace, nor righteousness no meed? (III.xi.9)

Virgil's Aristaeus complains to his goddess-mother, Cyrene, in a similar series of reproachful questions:

quo tibi nostri

pulsus amor? quid me caelum sperare iubebas?

en etiam hunc ipsum vitae mortalis honorem,

quem mihi vix frugum et pecudum custodia sollers

omnia temptandi extuderat, te matre relinquo.

quin age et ipsa manu felicis erue silvas...

tanta meae si te ceperunt taedia laudis. (Georgics 4.324-332)

['Whither have you banished love for me? Why did you bid me hope for heaven? Lo, even this very honour of my mortal life, which anxious care of my crops and livestock barely gained for me with all my efforts, I relinquish to you, mother. Why not go ahead and, with your own hand, rip up my fruitful woods...if such hatred of my glory has seized you?']

Alerted to his cries by another nymph, Arethusa, as they sit together in their subterranean cave, Cyrene comes to compassionate and aid her son, proving to him that his doubts are misplaced, and to the reader that a beneficent providence does after all favour the farmer's labour. Britomart too will act as a compassionate agent of Providence, allied as so often in Spenser to the power of chaste sexual love. But Aristaeus, in Virgil's text, is lamenting not the death of Eurydice, which he seems either not to have noticed or not to care about (we hear nothing of it until Proteus' account later in the episode), but rather the death of his bees, which grieves him because they were his possession, part of his livelihood, in which he had invested toil, and strikingly because he sees them as marks of his honor, his laus ('praise' or 'glory'). Virgil's model in this passage is Achilles' complaint to his mother, the sea-nymph Thetis, in Book 1 of the Iliad, where his grievance is that, by permitting Agamemnon to take from him the girl Briseis, his prize (geras) from a recent raid, Zeus has deprived him of the honour (time) which was to be his consolation for early death; Aristaeus' epithet for his bees in line 326, hunc ipsum vitae mortalis honorem ('this very honour of my mortal life'), particularly recalls Iliad I.352-56. ${ }^{36}$ A trace of such concerns is already present here in Scudamour's reference to 'meed'. Later, in Book IV, it will be a distinctive feature of Scudamour's attitude to Amoret, and of the attitude to the false Florimel among the knights at the tournament, that they view the ladies as trophies, possessions 'That many wish to win for 
glorie vaine, / And not for virtuous vse' (as Spenser says of Florimel's girdle, the prize in the ensuing beauty contest (IV.v.2)). Scudamour embarks on the rape of Amoret from the Temple of Venus 'To winne me honour' (IV.x.4). The quarrelsome knights who attack Britomart in the preceding canto find it 'full hard to read' whether they resent their defeat in the tournament because it deprived them of 'their priuate loues' or because it deprived them of 'their publicke praise' (IV.ix.36), for 'she had them both shamefully fordonne, / And eke the famous prize of beauty from them wonne'. (ix.28, my italics) But since what they call their love is so hollow and selfish, it comes in their case to the same thing: they value Florimel only as a 'famous prize', a possession bringing fame, and so her loss is simply part of the 'fowle vpbraide' Britomart has inflicted on their honour. Already in III.xi, Scudamour's resemblance to Aristaeus suggests that he views Amoret as an inhuman possession, like Aristaeus' bees, and is grieving not so much for her suffering as for his own loss. Aristaeus' connections to the Iliad in the fourth Georgic are a sign of something lofty in the conception of his character, suggesting the ways in which he anticipates the virtues Virgil will go on to celebrate in his own epic (not least by evoking his literal, biological conception by a goddess, like Achilles before him and Aeneas after). But the same resonances of Iliadic and Virgilian epic are for Spenser a cue for parody and ridicule, exposing the selfish pursuit of glory - and the predatory form of eros which goes with it — as less noble than the exercize of sympathetic love.

\section{A 'Prequel' and a Sequel to Spenser's House of Busirane}

Before turning to Florimel and Marinel, a glance at two other texts will help bring Spenser's House of Busirane episode into focus as a reworking of Orpheus' successful katabasis. The first is a mediaeval rendition of the Orpheus myth which adapts it in such a way as to make it strikingly resemble Spenser's episode; the second a text by Milton which clearly imitates at once the recovery of Eurydice and the rescue of Amoret, suggesting that Milton recognized the intimate connection between Spenser's episode and the Greek myth.

The early English romance, Sir Orfeo, was probably translated from a lost Old French lai in the thirteenth century. Its retelling of Orpheus' katabasis is remarkable in several ways, all resonating suggestively with Spenser's text. Firstly (and least surprisingly), the myth is given a new and anachronistic setting in a royal court, replete with knights and ladies, assimilating it to chivalric romance. Orfeo and Herodis are King and Queen, and the poem goes so far as to identify their realm as England, claiming that Thrace, where Orfeo holds his court, is an old name for Winchester. Secondly, the heroine doesn't die, but is abducted by the king of the fairies, and held captive not in the underworld but in his enchanted, golden palace in fairy-land, thus reading the classical myth through the lens of traditional Celtic fairy-lore, according to which many specific types of fatality were interpreted as abduction by the fairies rather than as actual death (leaving the possibility of return open). ${ }^{37}$ Thirdly, Orfeo recovers Herodis successfully, as in the pre-Virgilian tradition. Editors and most critics of the poem have seen this departure from the canonical Virgilian version as a quaint innovation in accordance with a sentimental approach to romantic love prevalent in the literature of the period (recalling the similarly Virgilio-centric approach of Spenserian critics). But an important article by Peter Dronke has shown that the pre-Virgilian tradition of the successful recovery persisted in eleventh-century France, and Peter Lucas (alone among critics of the 
poem) has argued that the poet of Sir Orfeo was consciously following it. ${ }^{38}$ Fourthly, the poem twins the theme of mutual love, which is poignantly emphasized, with that of social concord..$^{39}$ In grief after Herodis' abduction, Orfeo leaves his kingdom in the care of a steward. He returns with Herodis only after long years of absence, and the poem concludes with a substantial episode in which Orfeo, disguised as a wandering minstrel, tests the hospitality and loyalty of his household. They prove their hospitality by welcoming him and offering him food, their loyalty by responding with grief to his lying tale that he has seen their king dead; Orfeo reveals himself and is restored to the throne amid general rejoicing. This closing sequence is strikingly reminiscent of Odysseus' homecoming in the second half of the Odyssey: by what channels the poet might have known the Odyssey remains mysterious, but Dronke's study of the transmission of the Orpheus myth suggests that French poets of the period may have had more access to Greek literature than has been realized.

In Spenser's episode, we find the same combination of classical myth and chivalric romance, within the setting of a Faerie land riddlingly related to England (II.Pr.4). We have the same replacement of death with abduction to a similar richly decorated and enchanted palace. Perhaps Spenser - if he did not actually know the mediaeval poem-had heard versions of the Celtic stories of fairy abduction in his Irish home, and like the poet of Sir Orfeo perceived that they harmonized well with Orpheus' successful recovery of Eurydice in the Greek myth. Married love and social concord, the explicit themes of Books III and IV respectively, are inseparably intertwined in Spenser, as in the mediaeval poem. There are traces in this of the same combination of Orpheus and the Odyssey which informs Sir Orfeo: Odysseus' homecoming clearly underlies Britomart's arrival at Malbecco's house in III.ix. ${ }^{40}$ The Orphic dimension of the achievement of social concord, signalled most clearly by the allusion to Orpheus' quelling of the Argonauts' strife in canto ii, we shall deal with shortly. It is intriguing that Spenser's Busirane episode resembles so closely the explicit retelling of the Orpheus story in the mediaeval romance. Since Sir Orfeo was not, as far as we know, printed in the sixteenth century, any suggestion that Spenser may have read it (whether in manuscript or in some printed edition which has left no trace today) must remain purely speculative, though I find the idea attractive. ${ }^{41}$ But however this may be, the example of a poet whose choices, in his explicit version of Orpheus' katabasis, resemble Spenser's Busirane episode so closely, makes the lineaments of the Orpheus myth in III.xi and xii stand out more clearly.

My second triangulation is with Milton's Comus. Milton's Lady, as critics have observed, is both a Eurydice and an Orpheus, the captive maiden and the singer with magical powers. ${ }^{42}$ But Milton's masque is also deeply Spenserian, mingling strong evocations of Guyon's triumph over the Bower of Bliss from Book II of The Faerie Queene with equally strong evocations of the House of Busirane from Book III. ${ }^{43}$ Both Spenser's and Milton's episodes are scenes of midnight revelry in a 'stately palace' (Comus, stage direction following 1. 657), revels in which the ladies refuse to join, even as they refuse to yield to sexual seduction by their captors. In Spenser the revelry is explicitly described as a 'maske' (III.xii.5), the genre to which Milton's Comus belongs, and which, with its implicit moral critique of Stuart court culture, it subverts. When first assailed by the noise of Comus' revels, Milton's Lady tells us 'A thousand fantasies / Begin to throng into my memory / Of calling shapes, and beckning shadows dire,' (Comus 206-8); compare the threatening personifications of Busirane's masque which assail Amoret, 'So many...as there be phantasies 
/ In wauering wemens wit, that none can tell, / Or paines in loue, or punishments in hell'. (III.xii.26) The spectacle of Amoret,

both whose hands

Were bounden fast, that did her ill become,

And her small wast girt round with yron bands,

Vnto a brasen pillour, (III.xii.30)

underlies Comus' threat to the Lady, as she sits transfixed on the enchanted chair:

Nay Lady sit; if I but wave this wand,

Your nerves are all chained up in Alabaster,

And you a statue...' (658-60)

But Milton's image conflates the chained Amoret with a memory of the closing image of the 1590 edition, where the reunited lovers in their embrace are compared to 'that faire

Hermaphrodite, / Which that rich Romane of white marble wrought'. (1590, II.xii.46)

Milton's conflation of the two suggests that he has perceived the way in which Scudamour's attitude to Amoret, as we learn more about their relationship in Book IV, emerges as closely resembling Busirane's, casting an ironic light back over the cancelled ending of the 1590 edition, with its vision of their love as an ideal of mutuality and reciprocity. Britomart's first impulse on seeing Amoret in chains is to kill Busirane. Dissuaded from this by Amoret, who points out that only he can release her from the imprisoning enchantment, she instead forces him at swordpoint 'his charmes backe to reuerse,' (III.xii.35) at which the house quakes, the pillar shatters, and the rooms vanish (xii.37). In Milton, the Attendant Spirit's original plan is that the brothers should do the same, and he rebukes them when they rashly fail to observe his instructions:

Spir. What, have you let the false enchanter scape?

O ye mistook, ye should have snatched his wand And bound him fast; without his rod reversed, And backward mutters of dissevering power, We cannot free the Lady that sits here In stony fetters fixed, and motionless.... (813-18)

But ultimately it is the Orphic power of Sabrina's song which releases the Lady, fulfilling the Lady's earlier prediction that Orphic powers would bring about Comus' downfall. Were she to discourse on the 'sage and serious doctrine of Virginity', she there confidently asserts, her own inspired speech, charged with the sacred power of its subject, would destroy Comus' palace:

Thou art not fit to hear thy self convinced; Yet should I try, the uncontrolled worth Of this pure cause would kindle my rapt spirits 
To such a flame of sacred vehemence,

That dumb things would be moved to sympathize,

And the brute Earth would lend her nerves, and shake,

Till all thy magic structures reared so high,

Were shattered into heaps o'er thy false head. (Comus, 791-98)

The imagined scene obviously recalls the ruination of Busirane's house, brought about by Britomart, Spenser's embodiment of his own doctrine of Chastity (as well as anticipating the end of Samson Agonistes, where the divine origins of such power are foregrounded more explicitly). But at the same time the Lady describes her own oratorical powers in unmistakeably Orphic terms: Orpheus' famous ability to charm 'dumb things' with his music is trumped, in all the various accounts of the myth, only by his success in moving the pitiless gods of the Underworld to sympathy. Milton's masque represents another reworking of Orpheus' successful recovery of Eurydice, celebrating the power of divinely inspired and moralizing song, and of the 'sage and serious doctrine' his work promotes. His interweaving of this with allusions to his 'sage and serious poet, Spenser' shows that he recognizes Britomart's rescue of Amoret as another. ${ }^{44}$

\section{Poetry and Politics in the Tale of Florimel and Marinel}

Britomart's rescue of Amoret at the end of Book III, then, is a reworking of Orpheus' successful recovery of Eurydice, which takes Orpheus as symbolizing sympathetic love. In the other episode which reworks the rescue of Eurydice in Spenser's middle books - the rescue of Florimell from Proteus' dungeon at the end of Book IV-the Orphic capacity of song to elicit this kind of sympathy will be foregrounded explicitly, as the hitherto obdurate Marinell is moved to pity and love Florimell by overhearing her lament, thus becoming the only man to love her as a desiring subject, and not as a desirable object. Amoret and Florimel are paired in some very obvious and fundamental ways. Both are imprisoned by enchanters who seek to seduce them, their release from imprisonment forming the climax and end of Books III and IV respectively. Both flee from would-be rapists, yet both do so not out of any desire to remain virgins but out of fidelity to a beloved whom they actively pursue, just as Britomart pursues her Artegal. The same simile is attached to both:

Not halfe so fast the wicked Myrrha fled

From dread of her reuenging fathers hond:

Nor halfe so fast to saue her maydenhed,

Fled fearfull Daphne on th'Aegaean strond,

As Florimell fled from that Monster yond.... (III.vii.26)

echoed in the corresponding canto of Book IV, where Amoret flees Lust 'More swift then Myrrh' or Daphne in her race'. (IV.vii.22) In fact, they are neither like Daphne (because they do not wish to remain virgins) nor like Myrrha (because their desire, though sexual, is not incestuous or unchaste - Latin incestus). They are somewhere in between, or rather they resemble instead a figure not named in these similes-Eurydice, faithful bride of Orpheus, fleeing rape by Aristaeus. The epyllion of the fourth Georgic is also an important intertext for 
the story of Florimel and Marinel in Books III and IV. ${ }^{45}$ In fact, this narrative strand plays with the Virgilian source in a more intricate and multi-faceted way, and here the implications of Spenser's provocative rewriting of Virgil's Orpheus are not only to do with the ethics of love, but also to do with his very different view of the social and political role of the poet.

From his first appearance, in III.iv, Marinel's relationship with his mother, the seanymph Cymoent, is clearly intended to evoke Aristaeus' with his mother Cyrene. In Virgil, Cyrene and her nymphs compassionate Aristaeus, lamenting the death of his bees, lead him down into Cyrene's watery cave beneath the earth, and advise him to go and consult Proteus to discover how he can replenish his hives. In Spenser, Cymoent and her nymphs pity Marinel, and lead him to Cymoent's cave under the sea. In a flashback, we hear how Cymoent long ago consulted Proteus over her son's future. ${ }^{46}$ Marinel's life on the Rich Strond before his wounding by Britomart, focussed solely on advancing 'his name and glory' (III.iv.21) by 'great aduentures' (20) and wealth which makes him 'a great Lord appeare' (23), suggestively recalls Aristaeus' concern for his honor and laudes, and behind it Virgil's model of Achilles in the Iliad. The overarching theme of death and restoration to life which unites the intertwined stories of Aristaeus and Orpheus in Virgil's epyllion is sounded repeatedly throughout Spenser's narrative, with different variations. On first discovering her son, lying unconscious on the rich strond, Cymoent believes he is dead, and suffers her own metaphorical death as she swoons with grief: 'Had she not beene deuoide of mortall slime, / Shee should not then haue bene relyu'd againe' (III.iv.35). Her nymphs' lamentations recall those of Virgil's nymphs for the death of Eurydice, at Georgics 4.460-63, and her own laments approach Orphic heights of pathos, as 'the hard rocks could scarse from tears refraine' (III.iv.35). When one of the nymphs perceives that Marinel is not dead after all, Cymoent conveys him to her underwater bower, and sends for 'Tryphon of sea gods the soueraine leach' (III.iv.43), as she will again at IV.xii.23-24, when Marinel has suffered a relapse caused by the wound of his love for Florimel. Spenser gets the name 'Tryphon' from Boccaccio, where he is described as the brother of Aesculapius - the legendary doctor who restored the dead Hippolytus to life (and whose services Duessa sought on behalf of her lover Sansjoy in her own katabasis in Book I). ${ }^{47}$ But until the final canto of Book IV, the main point of Spenser's evocation of Virgil's fourth Georgic in this narrative strand seems to be to align Marinel with Aristaeus. This will change dramatically in IV.xii, as he and the myth undergo a simultaneous transformation, and Marinel goes from being, like Aristaeus, the unfeeling cause of Florimel's underworld imprisonment, to being an Orpheus whose descent contributes to her release, and like Orpheus an embodiment of sympathetic love.

Florimel is imprisoned from III.viii to the end of IV.xii in Proteus' cave under the sea, which combines Eurydice's underworld prison with Cyrene's and Proteus' caves from the fourth Georgic. At IV.xi.4 it is explicitly compared to 'the balefull house of lowest hell,' where Styx is to be found, and Florimel's period of imprisonment there is seven months, like Amoret's in the House of Busirane recalling the length of Orpheus' grieving in the fourth Georgic. Marinel, visiting Neptune's halls for the wedding of the Thames and Medway, overhears her lament at IV.xii.6-11. Her song is a passionate expression of love, but a love which is nevertheless unselfish and marked by true care for the beloved, as it moves from wishing that Marinel were with her in her prison in stanza 10, to wishing in stanza 11 that he may remain free and happy in the world above. It has the Orphic power of pathos, moving 
Marinel to pity, to care for the other and the wish to remedy her woes, and thus to Spenserian love. ${ }^{48}$ It sets in motion a chain reaction of events of sympathy which will lead to her release, as Cymoent exercises motherly compassion for Marinel's sympathetically conceived woe, and enlists the help of Neptune, a compassionate ruler, who compels Proteus to set her free. As the note on which Book IV ends, this image of a benign ruler compassionating his wronged subjects and restoring social harmony answers the Proem which opened the book, where Spenser invoked the help of Cupid and his mother to influence his own queen, Elizabeth, sprinkling her with 'drops of melting loue', and teaching her to put aside the 'vse of awfull Maiestie' and to govern with mildness and love. (IV.Pr.5) Over all these events presides Spenser himself, who foregrounds his own sympathy with Florimel when he returns to her story in Book IV:

But ah for pittie that I haue thus long

Left a fayre Ladie languishing in payne:

Now well away, that I haue doen such wrong,

To let faire Florimell in bands remayne,

In bands of loue, and in sad thraldoms chayne;

From which vnlesse some heauenly power her free

By miracle, not yet appearing playne,

She lenger yet is like captiu'd to bee:

That euen to thinke thereof, it inly pitties mee. (IV.xi.1)

As well as Ariostan humour, there is also a serious point here: Spenser foregrounds at once his own capacity for sympathy (recalling Britomart's) and the pathetic force of his poem to provoke sympathy in the reader (as we observed earlier of the narratorial interjections in III.xii). ${ }^{49}$ This is the same power of pathos by which Florimel's lament will move Marinel, and Spenser is of course the author of her lament and the source of its power. He as poet is himself the 'heauenly power' who will free her from her Underworld imprisonment, like Orpheus achieving the superhuman feat of his successful katabasis by moving the gods of the Underworld to unwonted pity.

Florimel is thus both an Orpheus and a Eurydice. The love that Marinel conceives for her is remarkable because it is inspired by her words, with their power to convey and to elicit sympathy for her inward feelings, rather than by her physical beauty, which has defined all male responses to her in the poem until now. Other men 'follow beauties chace' (III.i.19) in a way which makes their pursuit hard to distinguish from the rapacious desires of an Aristaeus, even when, like Arthur and Guyon in Book III, they seem (or think themselves) to be bent on rescuing her from a(nother) potential rapist. Until her release from Proteus' cave, Florimel has been in a state of perpetual flight from rape, like Eurydice at the beginning of her story in Virgil. Spenser's final reductio ad absurdum of a chivalric love which merely masks the rapist's selfish desire to possess the beautiful object is the parallel plot of the false Florimel, leading to the tournament of IV.iv. Here, Spenser is drawing on another part of the literary history of Orpheus' katabasis, Plato's version in the Symposium, where Orpheus is punished for his defective love (his unwillingness to sacrifice his own life for that of his beloved, as Alkestis did) by being given a phantom Eurydice in place of the real one. It is often observed 
that the knights who compete for possession of the false Florimel, and would be satisfied by this empty outward show of physical beauty, parody the warriors of the Trojan War, fighting for possession of what, according to Stesichorus' famous palinode, was only a phantom replica of Helen. ${ }^{50}$ But they are also failed Orpheuses in Plato's terms: like the Orpheus of the Symposium, they deserve only a phantom Eurydice, because their selfish desire is not the true love, which cares only for the good of the beloved and would prefer (as Florimel prefers at the end of her lament, and as Alkestis does in the Symposium) to forfeit life and remain in the underworld if only the beloved may go free. ${ }^{51}$

It is the false love and selfish desire of these knights, reflections of the defective Orpheus of Plato's Symposium, which lead to the repeated outbreaks of strife in Book IV. But Orpheus is also the figure who stands for the power to calm that strife and restore social concord, as the benign ruler Neptune will do at the end of the book. This social concord reflects on the political scale the friendship which is the explicit theme of the book, and which is so intimately connected with - indeed central to-Spenser's ideal of form of love (hence the friends as well as lovers who populate the Temple of Venus). It is also a speciality of Orpheus, as in the episode recounted in Apollonius' Argonautica (I.496-502), where his cosmogonic song calms the strife which has broken out between his fellow Argonauts on the eve of their setting sail. Spenser alludes to this altercation in canto i of Book IV, and to its resolution by Orpheus with 'his siluer Harpe' (IV.ii.1) at the beginning of canto ii. The prominence of this aspect of the Orpheus legend reflects the expansion in Book IV of Spenser's teachings on equity and liberty in love into his theme of equity and liberty within society as a whole.

Normally treated separately in the Renaissance, these two episodes in Orpheus' career - the quelling of the Argonauts' strife and the katabasis - are harmonized in Spenser. The Argonautica episode is brought closer to the katabasis in IV.ii by the observation that strife is a 'Firebrand of Hell first tynd in Phlegeton' (IV.ii.1), to be quelled only by such a 'godlike man' as Orpheus, who has overcome the normal limitations of humanity. Spenser's reworking of the katabasis in III.xi-xii, meanwhile, is as we have seen a triumph of sympathy and care which forms a striking contrast to the violence of Scudamour's rape recounted in IV.x. That account, we should recall, is immediately preceded by Arthur's Orpheus-like quelling of the strife between the companions Druon, Paridell, Claribell and Blandamour, and Britomart and Scudamour, on whom they have turned, 'with gentle words perswading them to friendly peace' (IV.ix.32). The gentle words with which Arthur achieves this renewal of social concord are precisely his reminder that to ladies 'the world this franchise euer yielded, / That of their loues choise they might freedom clame.' (IV.ix.37) The four knights are fighting (as at the tournament) over their right to possess the false Florimel as a trophy, an attitude quickly echoed by Scudamour, who asserts his 'right' to Amoret (ix.39), leading on to his account of the rape in the following canto. Britomart by contrast reminds the hostile knights and us that she did not take Florimel as her spoil in the tournament, 'but her had to her liking left' (36), in exact accordance with Arthur's precept, and her present anxiety over Amoret is again (as at the end of Book III) one of sympathetic care, contrasting with Scudamour's possessive desire: 'Aye me to see that gentle maid so tost,' she exclaims (ix.38). Arthur's term 'franchise' carries legal and political implications, its meanings including a privilege or right granted by a sovereign to an individual (OED 2b), freedom or 
exemption from servitude (OED 1a), and a right of asylum, or protection from arrest and imprisonment (OED 5); to 'enfranchise' is to set free (a slave or serf) (OED 1a), to set free from political subjection (OED 1b), or to release from confinement (OED 2a). The respect for the lady's own desire, advocated by Arthur, is at one with the sympathetic action by which Britomart literally frees Amoret from her imprisonment in III.xii, and with Marinel's sympathetic response to Florimel's lament, leading to her similar enfranchisement at the end of Book IV, by the agency of a compassionate ruler who prevents unjust oppression and protects the liberty of the weakest individuals in society. The equity and mutual care in love, which Spenser explores through his reworkings of Orpheus' rescue of his wife, is inseparably intertwined with the maintenance of social equity and concord by all those figures in Book IV who imitate Orpheus' feat in Book I of the Argonautica, quelling strife and averting violence by 'gentle words' - Glauce in Canto ii, Arthur in canto ix, and Neptune in canto xii. Orphic agency is identified in both spheres with the protection of individual liberty against coercion whether sexual or political, as Spenser seeks to exercise his Orphic powers over his audience to promote at once married love and social concord. ${ }^{52}$

\section{Conclusion}

Florimel's name means 'flower honey', from the Latin flos ('flower') and mel ('honey'), and her release from the underworld in Book IV evokes not only Eurydice's in the Greek version of the Orpheus myth, but also, and simultaneously, the rebirth of Aristaeus' bees in Virgil's bougonia. By combining the two, Spenser defies and undoes Virgil's polarization, in the epyllion and in his work more broadly, between love and art on one hand and politics and the public good on the other, and recuperates some of the positive values from Virgil's poem. In his elaborate opposition and counterpointing of Aristaeus and Orpheus, and in his imposition of failure on Orpheus' katabasis, Virgil reduces Orpheus to solipsistic self-absorption, love to a destructive madness, and art to the vain indulgence of individual emotion. The continuity of the species and of the state, meanwhile, are presented as depending on Aristaeus' qualities of labor and pietas, which Virgil suggests necessarily involve a callous lack of concern for the suffering of others, like the farmer's indifference to the nightingale's young destroyed by his plough. Aristaeus looks forward to the values celebrated in Virgil's epic, in which the future of Rome depends on Aeneas' pursuit of Iliadic martial conquest and active renunciation of love. In the ethos of the Aeneid, even art itself must be subordinated to the political destiny of Rome, as father Anchises instructs his descendants at the end of Book VI:

excudent alii spirantia mollies aera,...

tu regere imperio populos, Romane, memento

(hae tibi erunt artes)

[Others will smoothly fashion the breathing bronze...You, Roman, remember to guide the peoples with your rule (these shall be your arts)... (Aeneid VI.847-52).

It is this advice, to leave art to the Greeks, which Aeneas obtains as the fruit of his own katabasis, his equivalent to the journey on which Orpheus regained his wife by the power of his art. When Spenser chooses to merge Aristaeus' bougonia with Orpheus' katabasis, rather 
than opposing them as Virgil does, he undoes this separation of art and love from politics and the public good. The maintenance of society, and the survival of the species itself, symbolized in the restored supply of honey from Aristaeus' bees, is identified with, and shown to depend on, Orpheus' values of love and art. The Garden of Adonis, at the heart of Book III, reminds us, after all, that (unlike Virgil's sexless bees) all other life depends on sexual procreation to continue. When, after Amoret and Scudamour's reunion, Spenser ends the 1590 edition of The Faerie Queene with a more georgic version of the image which closes Virgil's second Georgic, replacing the chariot and smoking horses (with their distinctly epic and heroic associations) which Virgil uses as a metaphor for his composition (Georgics 2.541-2) with oxen and a plough (1590 III.xii.47), he is perhaps reflecting that his own poem celebrating this procreative fertility has the stronger claim to the kind of social utility Virgil's poem purportedly aspires to (while Virgil's is more concerned, in truth, with the military triumphs of the emperor). ${ }^{53}$

The shape of Virgil's career, with its claim to represent an ascent through subjects of increasing nobility and worth from humble amatory pastoral to imperialist epic, hinges on and is epitomized by the ascendancy of Aristaeus over the failed Orpheus of the fourth Georgic. That career taught Virgil's successors to see military conquest and the exercise of political power as the highest subject for song. Only the poet who celebrates and serves imperial power in epic can, according to the ideas Virgil bequeathed, be seen as promoting the public good or as a conduit of divinely sanctioned truth. And to be true to its genre, epic should, like the Aeneid, privilege Iliadic militarism and masculinity (though adapted to serve more nationalistic and imperialist ends than Homer ever envisaged) over the Odyssey's high valuation of married and familial love and relatively fluid conception of gender. Spenser's assumption of the role of the 'Brittayne Orpheus' must be understood in connection with his defiant reassertion of Orpheus' success in overcoming the tyrannical powers of the Underworld, which forms Spenser's central symbol of his rejection of this Virgilian valuesystem. Rather than a destructive madness, true love is for Spenser the highest subject for song, 'fayrest vertue, far aboue the rest' (III.Pr.1), root 'of honor and all vertue' (IV.Pr.2), and the fittest to be sung in epic. The vatic status of the epic poet, which for Virgil and the Virgilian tradition resides in political prophecy, in the Faerie Queene resides instead in the poet's ability to sprinkle his reader's heart with drops of melting love, gotten from sweet smiling Venus; his public service consists in promoting pity, mutual care and consentual politics as the basis of social concord. The legendary singer Orpheus, as evoked and refashioned by Spenser, embodies this set of counter-Virgilian values and ideas. Spenser's stern and insistent rejection of Virgil's version of the myth reminds a generation of gentlemen fashioned by their study of Virgil in Tudor grammar schools, that there is more to classical literature than Augustan imperialism, that rather than embodying some timeless essence of classical authority, Virgil reflects the circumstances of a particular, contingent moment in history, and fashions and distorts the substance of myth and poetry in the service of very particular political ends. Spenser invites his contemporaries, and us, to look back beyond Virgil, to remember the longer sweep of literary history, and to allow ourselves the freedom to choose from the wide array of ideas and values it makes available. 
${ }^{1}$ Thomas H. Cain, 'Spenser and the Renaissance Orpheus,' University of Toronto Quarterly 41 (1971), 24-47, at 24; Patrick Cheney, Spenser's Famous Flight: A Renaissance Idea of a Literary Career (Toronto: University of Toronto Press, 1993). See also Elizabeth Heale, 'Spenser as Orpheus,' in Autobiography and Authorship in Renaissance Verse: Chronicles of the Self (Houndmills: Palgrave MacMillan, 2003), pp. 92-124, and all the items mentioned in note 9 below.

${ }^{2}$ The Culex embroiders the Virgilian version here with a detail from Ovid, by having Orpheus look back 'seeking to kisse her', (Virgils Gnat 471) further emphasizing the role of erotic desire. On the poem's imitation of Virgil's three works, see Glenn Most, 'The Virgilian Culex,' in Michael Whitby, Philip Hardie and Mary Whitby (eds.), Homo Viator: Classical Essays for John Bramble (Bristol: Bristol Classical Press, 1987), pp. 199-209.

${ }^{3}$ Euripides' reference to Orpheus is at Alcestis 357-62; Plato's at Symposium 179d; and pseudo-Moschus, Lament for Bion at 11. 123-5. Other pre-Virgilian allusions to the myth, all implying a successful ending, can be found in Isocrates, Busiris II.8; Hermesianax, Leontion III; and Diodorus, Library of History 4.25.4 (the last being written during Virgil's lifetime).

${ }^{4}$ Merritt Y. Hughes, 'Greek Pastoral Triad' and T. P. Harrison, Jr., 'Spenser, Ronsard, and Bion,' MLN 49 (1934), 139-145 regard Spenser as knowing the Greek poem only through translations by the Pléiade; Michael O'Connell, 'Astrophel: Spenser's Double Elegy,' SEL 11 (1971), 27-35, argues for more direct imitation of the text. See also Syrithe Pugh, Spenser and Virgil: The Pastoral Poems (Manchester: Manchester University Press, 2016).

${ }^{5}$ C. M. Bowra, 'Orpheus and Eurydice,' Classical Quarterly 2 (1952), 113-26.

${ }^{6}$ As Brooks Otis observes, 'it is difficult to see what [Bowra's article] does except to suggest evidence where evidence does not exist. The important point, in any event, is that Virgil either invented or selected a very unusual variation of the myth'. (Brooks Otis, 'A New Study of the Georgics,' Phoenix 26 (1972), 40-62, at p. 58, n. 6.)

${ }^{7}$ For arguments emphasizing Virgil's agency in promoting the tragic ending, see Otis, 'A New Study of the Georgics,' Patricia Johnston, 'Eurydice and Proserpina in the Georgics,' TAPA 107 (1977), 161-72, and Howard Jacobson, 'Aristaeus, Orpheus, and the Laudes Galli,' AJP 105 (1984), 271-300.

${ }^{8}$ There are some, however. Among post-Virgilian Greek texts, see Plutarch, Amatores 17, Lucian, Dialogues of the Dead 2.3.3, and the scholiast on Euripides' Alcestis 357; and in Latin Statius, Thebaid 8.57-59 and Manilius, 5.326-28. For the mediaeval period, see chapter 1, footnote 20 below.

${ }^{9}$ On Epithalamion, see Joseph Loewenstein, 'Echo's Ring: Orpheus and Spenser's Career,' ELR 16 (1986), 287-302; Heale, 'Spenser as Orpheus'. On Faerie Queene IV.x, see Cain, 'Spenser and the Renaissance Orpheus,' 36-37; Dorothy Stephens, The Limits of Eroticism in Post-Petrarchan Narrative: Conditional Pleasure from Spenser to Marvell (CUP, 1998), pp. 63-64; Isabel MacCaffrey, Spenser's Allegory: The Anatomy of Imagination (Princeton: Princeton University Press, 1976), pp. 327-28; Maureen Qulligan, Milton's Spenser: The Politics of Reading (Ithaca: Cornell University Press, 1983), pp. 203-6; A. C. Hamilton (ed.), The Faerie Queene (New York: Longman, 1987), ad IV.x.58.4-5. On both, Judith Anderson, Reading the Allegorical Intertext : Chaucer, Spenser, Shakespeare, Milton (New York: Fordham University Press, 2008), p. $141,149-50$.

${ }^{10}$ Elena Theodorakopoulos, 'Closure: The Book of Virgil,' in Charles Martindale (ed.), The Cambridge Companion to Virgil (CUP, 1997), pp. 155-65.

${ }^{11}$ The Lament for Bion is the only pre-Virgilian bucolic poem to mention Orpheus. On the ways in which the Lament's insistence on the 'magical, Orphic dimension' of song is diffused and muted in Virgil's Eclogues, see Raymond Kania, 'Orpheus and the Reinvention of Bucolic Poetry,' AJP 133 (2012), 657-85.

${ }^{12}$ On the 'exquisite ambivalence' of the epyllion, see Jasper Griffin, 'The Fourth Georgic, Virgil, and Rome,' Greece and Rome 26 (1979), 61-80 (quotation at 71).

${ }^{13}$ Otis, 'A New Study of the Georgics,' 57-58; Robert Coleman, 'Gallus, the Bucolics, and the Ending of the Fourth Georgic,' AJP 83 (1962), 55-71.

${ }^{14}$ Jacobson, 'Aristaeus, Orpheus, and the Laudes Galli,' 295.

${ }^{15}$ M. C. J. Putnam, The Poetry of the Aeneid (Cambridge, Mass.: Harvard University Press, 1965), pp. 31-32; Monica Gale, 'Poetry and the Backward Glance in Virgil's Georgics and Aeneid,' TAPA 133 (2003), 337-38.

${ }^{16}$ Jane Tylus, 'Spenser, Virgil, and the Politics of Poetic Labor,' ELH 55 (1988), 53-77, perceives the tension between Spenser's 'attempt to validate the poet as an autonomous entity' and the way in which 'Virgil turns Hesiod's georgic into a poetics of patronage,' a process epitomized in his treatment of Orpheus. $(72,57)$ However, she seems unaware of the existence of a version of the myth in which Orpheus succeeds, and unaware too that 'Virgils Gnat' is a translation of the pseudo-Virgilian Culex. (She calls it 'a poem ironically named for the writer of the Georgics', p. 64.) 
${ }^{17}$ The absence of a clearly georgic work between Spenser's inaugural pastoral and his epic has often been mentioned as one of the 'problems' with seeing his career as Virgilian. (See for instance David Scott WilsonOkamura, 'Problems in the Virgilian Career,' Spenser Studies 26 (2011), 1-30.) In 'Spenser's Georgics,' ELR 10 (1980), 202-38, William Sessions traces the influence of the Georgics in The Faerie Queene's cultivation of virtue in the reader through the quasi-georgic labor of allegorical interpretation, with the Virgilian goal of 'redeeming a land and a history from the effects of time's disorders'. (203) But he identifies Virgil's narrowly political teleology too readily with Spenser's Protestant vision. His concession that 'Spenser has his own Christian transformation of the model, his own "household gods"' (224) would surely strike Spenser as a positively blasphemous understatement. No more than his disciple Milton does Spenser believe Virgil's teaching that time can be redeemed only by the absolutist rule of a self-deifying monarch. Meanwhile Sessions minimizes the tension between inspired art and Augustan destiny by averting his gaze from Virgil's treatment of Orpheus in the fourth Georgic, eliding it with Horace's very different emphasis on Orpheus' civilizing powers, and presenting Aristaeus as 'the new Orpheus' rather than as the antagonist who triumphs over him. (218-19) Among the many who have discussed Spenser's relation to and deviations from the Virgilian career path, Richard Neuse's argument, in 'Milton and Spenser: The Virgilian Triad Revisited,' ELH 45 (1978), 606-39, that Spenser replaces Virgilian georgic with epithalamion chimes with my observations in this paper.

${ }^{18}$ Pugh, Spenser and Virgil, 33-37, 279-92.

${ }^{19}$ Hamilton also seems to be thinking of the moralizing commentaries following Boethius, which commonly made this into an explicit lesson about the dangers of worldly desire and fleshly love.

${ }^{20}$ Hamilton makes no mention of Orpheus and Eurydice in the glosses to the stanza on the abduction itself in canto i, however.

${ }^{21}$ Lauren Silberman makes the connection between IV.x and Aristaeus' attempted rape: Transforming Desire: Erotic Knowledge in Books III and IV of The Faerie Queene (Berkeley: University of California Press, 1995), p. 85.

${ }^{22}$ James Nohrnberg makes this connection: The Analogy of The Faerie Queene (Princeton: Princeton University Press, 1976), p. 489.

${ }^{23}$ This faint-heartedness is perfectly in keeping, meanwhile, with the neglect which allows Amoret to be abducted on her wedding day (IV.i.3). In 'The Sincerity of Rapture,' Andrew Escobedo notes 'a recurring unsteadiness in [Scudamour's] character, so that he asserts his will excessively or insufficiently, and seems to us alternately silly and dangerous', arguing that this is a sign of his insincerity as a lover who has not undergone a true Platonic rapture, and thus remains 'able to calculate his actions with an eye to self-interest.' Escobedo ends by suggesting a parallel between Scudamour and the Orpheus of the Symposium, punished for his defective love by being given a phantom Eurydice in place of the real one. As we shall see below, the knights at the tournament in Book IV, whose motives resemble Scudamour's closely, are punished precisely with an imitation of Plato's version of the myth, when they compete for the false Florimel.

${ }^{24}$ E.g. A. Kent. Hieatt, 'Scudamour's Practice of Maistrye upon Amoret,' PMLA 77 (1962), 313-18; Elizabeth Fowler, 'The Failure of Moral Philosophy in the Work of Edmund Spenser,' Representations 51 (1995), 47-76 (esp. 56-59).

${ }^{25}$ They are the first words she speaks in the poem, so that this is recognition appears almost to define her, as it certainly defines the idea of love she represents. Her final act in the poem, releasing Artegal from his imprisonment by Radigund, will also be an attack on such erotic 'maistrye'. This episode again echoes Orpheus' release of Eurydice, though with the genders this time switched altogether, and thus bringing out the political resonances of Spenser's doctrine of franchise in love, by reflecting with all the more satirical specificity on the Petrarchan rule of Elizabeth over her courtiers. (It also focusses attention the more acutely on issues of political consent and tyranny because Artegal's true gender forbids any lapse on the reader's part into an assumption that his subject state is somehow 'natural'. On the political allegory of this episode, see Jeffrey B. Griswold, 'Allegorical Consent: The Faerie Queene and the Politics of Erotic Subjection,' Spenser Studies 29 (2014), 21937.)

${ }^{26}$ On the education of the lover in the Amoretti, see W. C. Johnson, 'Spenser's "Greener" Hymnes and Amoretti: "Retractation" and Reform,' ES 73 (1992), 431-43 and 'Gender Fashioning and the Dynamics of Mutuality in Spenser's Amoretti,' ES 74 (1993), 503-19.

${ }^{27}$ Anderson's suggestion (Reading the Allegorical Intertext, pp. 150-51) that Scudamour might be the 'warie Hynd' here is unconvincing: it rests on the idea that hunters and their hounds employ 'intreatie' to persuade a deer to leave its safe haven and be killed, and even more counter-intuitively identifies the deer's safe haven as its 'spoyle'. 'Spoil' — plunder or goods seized by force, as in war — would be a bizarre name for a potential victim's last refuge from violence, but on the other hand is a natural term for the deer itself. Indeed, it is derived from the Latin spolium, a word whose Greek root means the hide of an animal, stripped from its body; its original significance is thus to do with hunting, and is transferred thence to warfare in the common Latin usage to refer to arms stripped from the body of a defeated warrior. Spenser is, if anything, returning the term to its original meaning with etymological precision, rather than creating the ambiguity Anderson suggests. 
${ }^{28}$ The trope is at least as old as Plato (see for instance Sophist 222d, Laws 823b), but it is especially favoured by Ovid, on which see for instance C. M. C. Green, 'Terms of Venery: Ars amatoria I,' TAPA 126 (1996), 221-63; Gregson Davis, The Death of Procris: 'Amor' and the Hunt in Ovid's Metamorphoses (Rome: Edizioni dell'Ateneo, 1983).

${ }^{29}$ In an article which valuably reminds us that 'female characters in The Faerie Queene represent not only actual women but also political subjects,' (252) Melissa E. Sanchez takes the revised account of the beginning of the relationship in IV.x as a reflection of Spenser's unease over the increasingly absolutist tendencies of Elizabeth's government in the 1590s, exposing the reality of unjust oppression underlying the rhetoric of mutual and harmonious love between ruler and ruled in contemporary political discourse. While Sanchez is right to insist on the political import of love relationships in the poem, I disagree with her inference that Amoret's love is retrospectively revealed as wilfully and culpably self-deluded, like the subjects of tyrants blamed by Etienne de la Boétie, in his Discours de la Servitude volontaire, for colluding in their own oppression. Such a reading implies that Scudamour's account is true and the account in III.vi false, but that kind of discrimination is not necessary in an allegorical poem as it would be in a realist novel. Until IV.x, Spenser intends us to view Amoret's sufferings in the light of the III.vi account, and to approve of her fidelity to her (freely) chosen mate, which reveals her virtuous understanding of love as well as her virtue in love. Scudamour's account in IV.x then reveals his shockingly different attitude to and perception of their relationship, and of love relationships in general. For him, love is all about the self, and the achievement of selfish desires: Amoret is an object to be possessed, and a trophy whose possession proves his manly ability to achieve his desires by force. He does not value her consent, because he has no interest in love as 'mutuall goodwill'. He does not care whether she loves him or not; perhaps he doesn't even notice. In a way, it makes a better story for his purposes if she does notone which displays not only his strength and valour, but also his Stoical immunity to female wiles ('tender teares' and 'witching smyles'). He is revealed as not deserving Amoret's love, certainly, but this is a measure of his blindness, not hers.

${ }^{30}$ Compare David Lee Miller's suggestive remarks on Scudamour as 'a failed counterpart to the poet-speaker of Spenser's sonnet sequence and marriage poem,' and sonnet 67 as 'a delicately crafted antithesis to Scudamour's mastery' in IV.x. ('The Chastity of Allegory,' 1, 14)

${ }^{31}$ On E.K.'s glosses in October in relation to Spenser's views on poetic inspiration, see Louise Schleiner, 'Spenser and Sidney on the Vaticinium,' Spenser Studies 6 (1986), 129-45.

32 'The Chastity of Allegory,' 11-12.

${ }^{33}$ Ars amatoria I.655-8; Ovid's praeceptor quickly follows this up with advice that rape is permissable, dissolving any concern for the woman's will in the paradoxical argument that quod iuvat, invitae saepe dedisse volunt ('often they wish to have given against their will that which gratifies them,' I.674).

${ }^{34}$ See the remarks of Judith H. Anderson, in 'Busirane's Place: The House of Rhetoric,' Spenser Studies 17 (2003), 143-45.

${ }^{35}$ On Virgil's Arethusa in relation to Spenser's doctrine of love, see Pugh, Spenser and Virgil: The Pastoral Poems, 238-48.

${ }^{36}$ See Coleman, 'Gallus, the Bucolics, and the Ending of the Fourth Georgic,' p. 66; Richard F. Thomas (ed.), Virgil: Georgics (CUP, 1988), ad 315-32 and ad 326. In the light of what we shall have to say later about Sir Orfeo, it is interesting to note that, if Virgil aligns Aristaeus with Achilles, he aligns Orpheus with Homer's other hero, Odysseus. Odysseus similarly visits the Land of the Dead, of course, and Virgil's account of Orpheus' katabasis contains echoes of this episode (on which see Thomas, Georgics, ad 471-80, to which I would add that the effect of his song on the very halls of Hades (4.481-84) recalls the spell-binding effect of Odysseus' bard-like narrative on the court of Alkinoos at 11.333-34=13.1-2). But chiefly the Odyssean echoes evoke Odysseus' affective family bonds: Eurydice's vanishing at 499-502 recalls Odysseus' frustrated attempt to embrace the shade of his mother at Odyssey 11.204-8, as well as its nearer model (Achilles' attempt to embrace Patroklos' ghost); and the simile at 4.511-15 comparing Orpheus' lamentation to that of the bereaved nightingale combines (as Thomas notes ad loc.) allusions to Odyssey 19.518, where Penelope compares herself to Philomela lamenting the death of Itys, and to Odyssey 16.216-18, where the shared laments of Odysseus and his son Telemachus on their reunion are compared to the cries of birds whose young have been taken by farmers.

${ }^{37}$ Dorena Allen, 'Orpheus and Orfeo: The Dead and the Taken,' Medium AEvum 33 (1964), 102-11.

${ }^{38}$ P. Dronke, 'The Return of Eurydice,' Classica et Mediaevalia 23 (1962), 198-215; Peter J. Lucas, 'An Interpretation of Sir Orfeo,' Leeds Studies in English n.s. 6 (1972), 1-9.

${ }^{39}$ Roy Michael Liuzza, 'Sir Orfeo: Sources, Traditions and the Poetics of Performance,' Journal of Medieval and Renaissance Studies 21 (1991), 269-84.

${ }^{40}$ More broadly, Spenser's narratives of ladies questing for their male beloveds are twice paralleled with Odysseus' quest to return to his wife. Una, in search of Redcrosse, is explicitly compared to 'that long wandring Greeke,/That for his loue refused deitye,' at I.iii.21. When Britomart finds Artegal in Radegund's palace, her astonishment at his uncouth appearance (for he is dressed in women's clothes) is compared to that of Penelope 
at Odysseus' homecoming, barely recognizable after his twenty years' absence (V.vii.39). Of course, the witty point is that Spenser's cross-dressed characters here conform very neatly to the opposite identification: it is Britomart (disguised as a male knight) who, like Odysseus, has arrived to rescue her beloved, where he sits Penelope-like with his distaff, besieged by unwanted suitors. The gender reversal involved here is a striking feature of the Odyssey itself, with its similes likening Odysseus to a woman (8.523-31) and Penelope to a man (19.107-11); Spenser also plays with such gender reversals, with allusion to Penelope and Odysseus, in Amoretti 23.

${ }^{41}$ As well as allowing that Spenser may have read mediaeval manuscripts, Andrew King emphasizes that 'Certainly, more Middle English romances reached print than those that survive.' (The Faerie Queene and Middle English Romance: The Matter of Just Memory (Oxford: Clarendon Press, 2000), p. 37)

${ }^{42}$ Patricia Vicari, 'The Triumph of Art, the Triumph of Death: Orpheus in Spenser and Milton,' in John Warden (ed.), Orpheus: The Metamorphoses of a Myth (Toronto: University of Toronto Press, 1982), pp. 207-30, at 21723; Rachel Falconer, Orpheus Dis(re)membered: Milton and the Myth of the Poet-Hero (Sheffield: Sheffield Academic Press, 1996), pp. 51-62.

${ }^{43}$ On Comus in relation to the House of Busirane, see Vicari, 'The Triumph of Art,' pp. 217-19, and Quilligan, Milton's Spenser, pp. 209-212; on its relation to Book II of The Faerie Queene, see for instance Catherine Gimelli Martin, 'The Non-Puritan Ethics, Metaphysics, and Aesthetics of Milton's Spenserian Masque,' Milton Quarterly 37 (2003), 215-44.

${ }^{44}$ The obvious difference between Milton's 'virginity' and 'Chastity' as Spenser defines it in Britomart does not present a real obstacle here: Milton's Lady is played by, and represents, a fifteen-year old girl, and her chaste opposition to Comus' hedonistic ethos is fitting to her as-yet-unbetrothed state. Indeed, the Attendant Spirit's final speech alludes strongly (at 999-1008) to Spenser's Garden of Adonis, suggesting fruitful marriage as a rite of passage which lies in the Lady's future. There is perhaps even a suggestion that Milton's Attendant Spirit, who dons the disguise of a shepherd (with his own enchanting musical skill) to keep watch over and guide the community, represents the Orphic poet Spenser in his familiar pastoral persona.

${ }^{45}$ Nohrnberg connects the Marinel-Florimel story with the fourth Georgic briefly at Analogy, p. 590.

${ }^{46}$ Spenser recognizes and activates the Iliadic intertext of Virgil's episode here. Aristaeus' encounter with Cyrene evokes Achilles' with Thetis in Book I of the Iliad, and also Thetis' presence with her nymphs as mourners at Patroklos' funeral in Book 18. (See Coleman, 'Gallus, the Bucolics, and the Ending of the Fourth Georgic,' p. 66.) Spenser's Marinel is similarly aligned with Achilles, as Cymoent and her nymphs not only compassionate but actively mourn him, believing him dead, recalling the mourning of Thetis and her nymphs in Iliad 18. Proteus' prophecy regarding Marinel, meanwhile, evokes the double destiny which Thetis informs Achilles he has carried from the day of his birth - long but inglorious life or early death followed by immortal fame. The actual mechanism of Marinel's unexpected downfall in Book III evokes the extra-Iliadic addition to the story of Achilles (which Spenser could have known from Fulgentius' Mythologiae 3.7), Thetis' attempt to charm his life by dipping him into the Styx, leaving vulnerable only the heel by which she held him, and his ultimate demise as a result of love, when shot in the heel by Paris during his tryst with Polyxena.

${ }^{47}$ Boccaccio, De genealogia deorum gentilium, VII.xxxvi; noted by Henry Gibbons Lotspeich, Classical Mythology in the Poetry of Edmund Spenser (Princeton, 1932), p. 113, and Hamilton ad III.iv.43.7-9.

${ }^{48}$ Silberman, Transforming Desire, p. 136 and n. 27 connects Marinel's descent to Orpheus' katabasis and Florimel's lament to Orpheus' plea in the Underworld.

${ }^{49}$ Compare the opening of IV.i, where Spenser confesses that 'deare compassion' of both Amoret and

Florimel's suffering 'My softened heart so sorely doth constraine, / That I with teares full oft doe pittie it, / And oftentimes doe wish it neuer had bene writ.'

${ }^{50}$ Thomas P. Roche, The Kindly Flame: A Study of the Third and Fourth Books of Spenser's Faerie Queene (Princeton: Princeton University Press, 1964), pp. 153-55; Nohrnberg, Analogy, pp. 115-17, 482, 572; Mihoko Suzuki, Metamorphoses of Helen: Authority, Difference, and the Epic (Ithaca: Cornell University Press, 1989), 173-77. For Stesichorus' palinode, see Plato, Phaedrus 243a-b and Republic 9.586c.

${ }^{51}$ As Escobedo suggests of Scudamour, whose motives resemble theirs (see n. 21 above).

${ }^{52}$ On Spenser's treatment of rape in relation to 'a political philosophy that emphasizes consent, mutuality, and social bonds,' see Elizabeth Fowler, 'The Failure of Moral Philosophy in the Work of Edmund Spenser,' Representations 51 (1995), 47-76 (quotation at 56).

${ }^{53}$ On The Faerie Queene in relation to Virgil's Georgics, see also Linda Gregerson, 'Spenser's Georgic: Violence and the Gift of Place,' Spenser Studies 22 (2007), 185-201 and Andrew Wallace, “'Noursled Up in life and manners wilde": Spenser's Georgic Educations,' Spenser Studies 19 (2004), 65-92. Looking at Book I together with the Viewe of the Present State of Ireland, Gregerson finds that 'Spenser never resolves the violence inherent in human cultivation': the emphasis on consensual politics I have been tracing here does not extend to the colonial situation. Wallace, meanwhile, is concerned with Spenser's cultivation of the reader, showing how Spenser engages with 'the georgic metaphors that humanist educators adduced as explanatory fictions for instruction.' (65) For Wallace, Spenser shares Erasmus' simultaneous fear that such 'georgic 
metaphors' may encourage brutal pedagogic methods, and thereby teach brutality by example, because they 'proceed by objectifying and then subduing violently the "uncultivated" student.' (83) We should note that Orpheus also offers an alternative method and example. Like the Virgilian farmer, he too 'subdu[es] the wild intractability of natural savagery' (77) when he charms the beasts of the forest with his song, but he does so not by exerting physical force to constrain their bodies, but by harnessing their emotion and will with the pathos of his music. The scene was traditionally allegorized as representing the poet's civilizing power. This Orphic pedagogy, which cultivates and works with the good will of its readers, is more central to Spenser's didactic method than the violence of georgic proper. Concentrating on georgic imagery, Wallace finds 'a diminished claim for poetry as a teaching instrument' (84) in the 1596 edition of The Faerie Queene; I would respond that, in the release of Florimel and in the Acidalian vision of Book VI, Spenser continues to insist on this Orphic form of teaching, with its claims to vatic inspiration and its emphasis on persuasion rather than subjugation. 